\title{
LATENT LIVER DISEASE IN PERSONS RECOVERED FROM CATARRHAL JAUNDICE AND IN OTHERWISE NORMAL MEDICAL STUDENTS AS REVEALED BY THE BILIRUBIN EXCRETION TEST
}

\author{
BY ARTHUR KORNBERG \\ (From the Department of Medicine, University of Rochester School of Medicine and Dentistry \\ and the Medical Clinics, Strong Memorial and Rochester Municipal \\ Hospitals, Rochester, New York)
}

(Received for publication December 29, 1941)

The frequency with which chronic non-hemolytic jaundice occurs in otherwise healthy young persons is not commonly recognized, nor is it usually appreciated how often an uncomplicated attack of catarrhal jaundice is followed by residual liver dysfunction which persists long after the acute episode.

The present study was prompted by the accidental discovery of a relatively large number of medical students with chronic jaundice and a history of a previous attack of catarrhal jaundice in two of them. A group of persons long recovered from catarrhal jaundice was investigated and also a control group of persons presumably normal. The bilirubin excretion test was used in all cases because of its reliability in detecting lesser degrees of liver dysfunction.

\section{METHODS}

Bilirubin excretion test. The method of Von Bergmann and Eilbott $(1,2)$ was used with modifications. Bilirubin (Eastman Kodak) was given under basal conditions in a dose of $1.5 \mathrm{mgm}$. per kilogram of body weight. No untoward reactions were observed when fresh materials were used. A retention at 4 hours in excess of 15 per cent was regarded as abnormal.

Bilirubin determination, qualitative and quantitative. The photoelectrometric method of Malloy and Evelyn (3) was used. Hemolysis was avoided and analyses which failed to check within 2 per cent were rejected. The Evelyn colorimeter manual gives the range of normal serum values for direct bilirubin as 0.1 to $0.4 \mathrm{mgm}$. per cent and for indirect (total) bilirubin as 0.2 to $0.7 \mathrm{mgm}$. per cent. The ratio of the direct to indirect bilirubin is given clinical significance when elevated values occur. The ratio is high ( 0.60 to 0.80$)$ in obstructive jaundice, intermediate $(0.25$ to 0.55$)$ in diffuse parenchymal damage, and low (0.15) in hemolytic jaundice.

Bromsulphalein excretion test. A dose of $5 \mathrm{mgm}$. per kilogram of body weight was injected intravenously and a retention in excess of 10 per cent at 30 minutes was regarded as abnormal. Galactose tolerance test. Forty grams of the sugar were given orally; a urinary output of more than 3 grams within 5 hours after ingestion was regarded as indicative of liver damage. Cholecystogram. A dose of tetraiodophenolphthalein was administered orally 18 and 12 hours before the test. Fragility of red blood cells to hypotonic solutions of sodium chloride. The method of Waugh and Asherman (4) was used with saline. Determinations were made with the Evelyn colorimeter. Sedimentation rate. The Wintrobe method was used. Values from 0 to $9 \mathrm{~mm}$. per hour were regarded as normal for males. Reticulocyte count. The "wet" method was used. A drop of capillary ear blood was placed on a dry film of cresyl blue (in saturated alcohol solution), and the reticulocytes in 1000 red blood cells were counted. The normal range was considered to be 0 to 2.5 per cent. Urobilin. The Schlessinger reaction was used for the qualitative determination of urobilin in the urine. A definite fluorescence in the filtrate was a positive test. Urobilinogen. Ehrlich's aldehyde method was employed for the detection of excess urobilinogen in the urine. A red color in a dilution greater than $1: 10$ was a positive test. Vitamin $A$ absorption test and plant pigment determination. The method of Chesney and McCoord was used. Fish liver oil containing 7000 U.S.P. vitamin A units for each kilogram of body weight was given. The vitamin A content of the blood was measured by the McCoord and Luce-Clausen (5) modification of the Carr and Price technique. The analysis for the carotenoids or plant pigments (xanthophyll and carotene), which was necessary for the correction of vitamin A results, was done by the method of Clausen and McCoord (6).

\section{RESULTS}

1. Persons presumed to be normal. For this group, subjects were selected who gave no indication of liver dysfunction by history or physical examination. They were in the younger age groups and were recovering from minor surgical operations.

The basal serum bilirubin concentrations which were generally below $0.8 \mathrm{mgm}$. per cent are in Table I, and the individual values during the excretion test are in Table II. Of 22 persons tested, 95 per cent retained less than 15 per cent of the injected bilirubin and 73 per cent retained less than 10 per cent. The sole person who retained 
TABLE I

Distribution of basal bilirubin values in persons presumed to be normal

Range: $\quad 0.114 \mathrm{mgm}$. per cent to $0.900 \mathrm{mgm}$. per cent Mean concentration:

$0.398 \mathrm{mgm}$. per cent

Standard deviation:

$0.184 \mathrm{mgm}$. per cent

\begin{tabular}{ccc}
\hline \hline Serum bilirubin & Number of cases & Per cent of total \\
\hline mgm. per cent & 3 & 10 \\
$0.000-0.199$ & 11 & 38 \\
$0.200-0.399$ & 12 & 41 \\
$0.400-0.599$ & 2 & 7 \\
$0.600-0.799$ & 1 & 4 \\
$0.800-0.999$ & 29 & 100 \\
\hline Total & & \\
\hline
\end{tabular}

TABLE II

Individual bilirubin excretion test values in persons presumed to be normal

Per cent retention at 240 minutes

$$
=\frac{C_{240 \text { minutes }}-C_{0 \text { minutes }}}{C_{5 \text { minutes }}-C_{0 \text { minutes }}} \times 100
$$

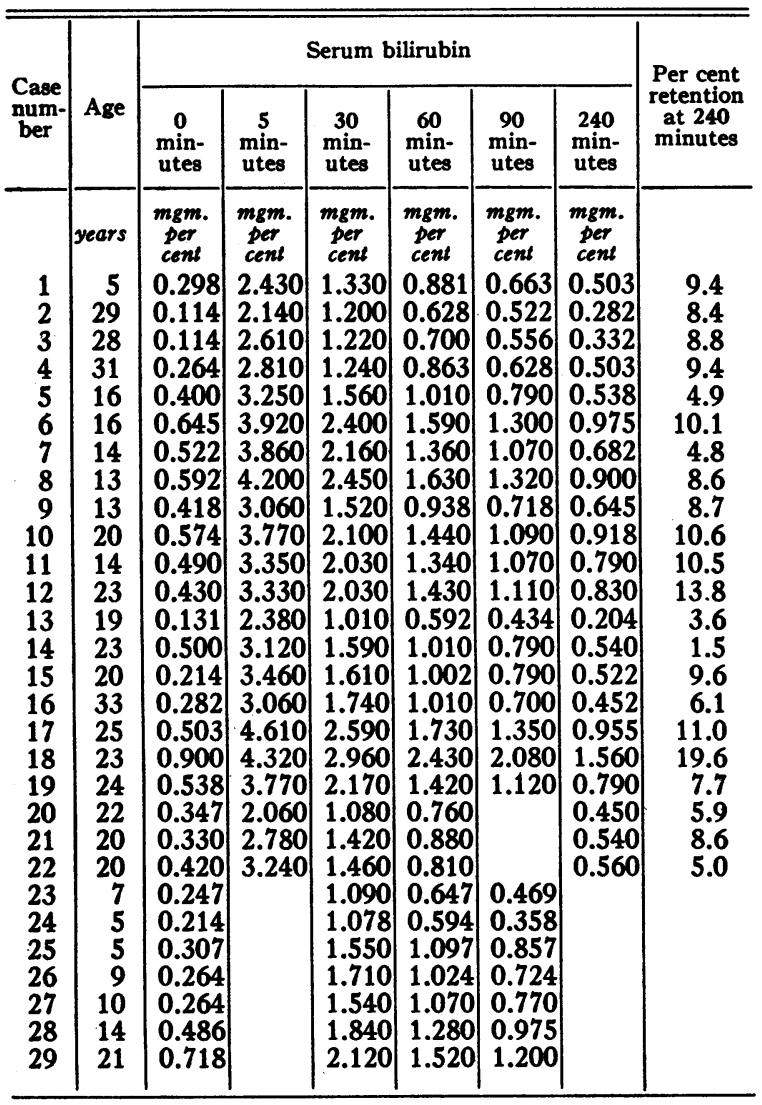

in excess of 15 per cent of the injected bilirubin was the one who had the extreme basal bilirubin value of $0.900 \mathrm{mgm}$. per cent. Mean bilirubin values at various time intervals during the test are
TABLE III

Mean bilirubin excretion test values in persons presumed to be normal and others long recovered from catarrhal jaundice

The values at 0 minutes are the basal bilirubin levels. $C_{i}-C_{0}=$ Concentration at time, " $i$," minus basal bilirubin concentration, " 0 ". The mean bilirubin values are followed by their standard errors. The mean values for the two groups were significantly different at each time period except the one at 5 minutes.

\begin{tabular}{|c|c|c|c|c|c|c|}
\hline \multirow[b]{2}{*}{ Time } & \multicolumn{3}{|c|}{ "Normal" group } & \multicolumn{3}{|c|}{$\begin{array}{c}\text { "Post-catarrhal jaundice" } \\
\text { group }\end{array}$} \\
\hline & $\begin{array}{l}\text { Num- } \\
\text { ber } \\
\text { of } \\
\text { cases }\end{array}$ & $\begin{array}{c}\text { Mean value } \\
\left(C_{i}-C_{0}\right)\end{array}$ & $\begin{array}{c}\text { Coef- } \\
\text { ficient } \\
\text { of vari- } \\
\text { ation }\end{array}$ & $\begin{array}{c}\text { Num- } \\
\text { ber } \\
\text { of } \\
\text { cases }\end{array}$ & $\begin{array}{l}\text { Mean values } \\
\left(C_{i}-C_{0}\right)\end{array}$ & $\begin{array}{l}\text { Coef- } \\
\text { ficient } \\
\text { of vari- } \\
\text { ation }\end{array}$ \\
\hline $\min _{\text {utes }}$ & & & & & & \\
\hline $\begin{array}{r}0 \\
5 \\
30 \\
60 \\
90 \\
240\end{array}$ & $\begin{array}{l}29 \\
22 \\
29 \\
29 \\
26 \\
22\end{array}$ & $\begin{array}{l}0.396 \pm 0.034 \\
2.760 \pm 0.106 \\
1.320 \pm 0.065 \\
0.710 \pm 0.048 \\
0.490 \pm 0.039 \\
0.240 \pm 0.030\end{array}$ & $\begin{array}{l}0.460 \\
0.181 \\
0.268 \\
0.366 \\
0.408 \\
0.584\end{array}$ & $\begin{array}{l}17 \\
16 \\
17 \\
17 \\
17 \\
17\end{array}$ & $\begin{array}{l}0.616 \pm 0.061 \\
2.940 \pm 0.080 \\
1.650 \pm 0.085 \\
1.120 \pm 0.085 \\
0.870 \pm 0.085 \\
0.540 \pm 0.073\end{array}$ & $\begin{array}{l}0.408 \\
0.109 \\
0.212 \\
0.312 \\
0.402 \\
0.506\end{array}$ \\
\hline
\end{tabular}

in Table III. Figure 1 contains a composite curve of these mean bilirubin values, and Figure 2 shows the linear relationship which is obtained when these values are plotted against the logarithm of time.

2. Persons long recovered from catarrhal jaundice. The subjects for this group were chosen completely at random from the hospital records of adequately studied and confirmed cases of acute catarrhal jaundice. They were generally children or young adults who, during their acute episode of jaundice, had symptoms of malaise, nausea, and abdominal pain. There was a sudden onset of jaundice which often coincided with symptomatic improvement. A familial incidence was noted in half of the cases. Fever, hepatomegaly, leukopenia with an increase in the percentage of mononuclear cells, bilirubinuria, and acholic stools were found in most cases. Hyperbilirubinemia was always present with an immediate direct van den Bergh reaction when tested. Treatment was symptomatic and recovery in each case was rapid and uneventful, with a prompt fall of the serum bilirubin level to near normal limits.

Individual serum bilirubin values during the excretion test are shown in Table IV, and the mean values in Table III. The latter have been shown to differ significantly from those for the "normal" group. Of 16 persons tested, 63 per cent retained more than 15 per cent of the in- 


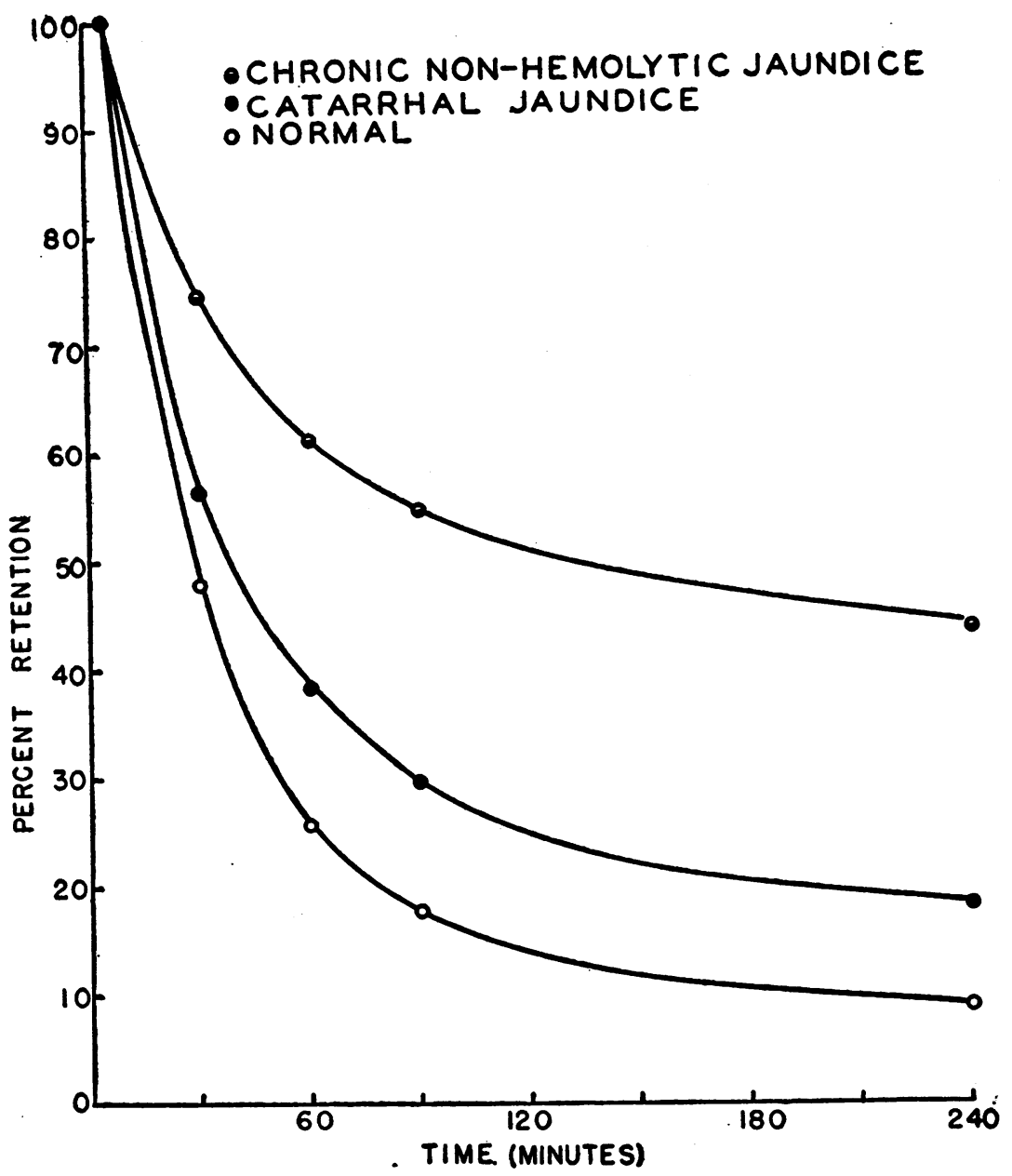

Fig. 1. Composite Curves of Mean Serum Bilirubin Values during the EXCRETION TEST

jected bilirubin and 95 per cent retained more than 10 per cent. Composite curves for the data in Table III are in Figures 1 and 2.

Among the 10 persons who showed an abnormal bilirubin excretion curve, a history at the time of the test revealed 4 with symptoms suggestive of liver dysfunction (Cases 30, 33, 40, 45), 3 with only vague abdominal pains or anorexia (Cases 35 , 37,44 ), and 3 without any symptoms (Cases 31 , $32,36)$. The pertinent clinical data of 5 of these 10 patients are presented here.

Case 30. A 12-year-old boy has been followed in the pediatric clinic since the age of 6 years for enuresis, habit spasms, and temper tantrums. His father has a convulsive disorder, and the home environment is unstable. In October 1940 he had an attack of catarrhal jaundice and was discharged after 5 days. In the Out-Patient Depart- ment he complained of anorexia, fatigue, malaise, right upper quadrant tenderness, and mild epigastric pain. Four months after discharge he was readmitted to the hospital for severe paraumbilical pain, nausea, vomiting, marked distension, and foul flatus. The only positive findings were a flat glucose tolerance curve and an abnormal excretion of bilirubin despite normal basal bilirubin values. Supportive care eased the symptoms, and he was discharged with the diagnosis of aerophagia. He continued to be irritable, became fatigued easily, and complained of diffuse abdominal pain, nausea, flatulence, headaches, and severe constipation. Two weeks later he returned to the hospital with frank jaundice, an enlarged tender liver, and a readily palpable spleen. Again complete hematological, chemical, and $x$-ray studies were entirely negative, except for a basal bilirubin level of 1.22 mgm. per cent and a bilirubin retention of 41.8 per cent. Other tests of liver function were repeatedly negative. After a 2-week dietary regime of low fat and high car- 


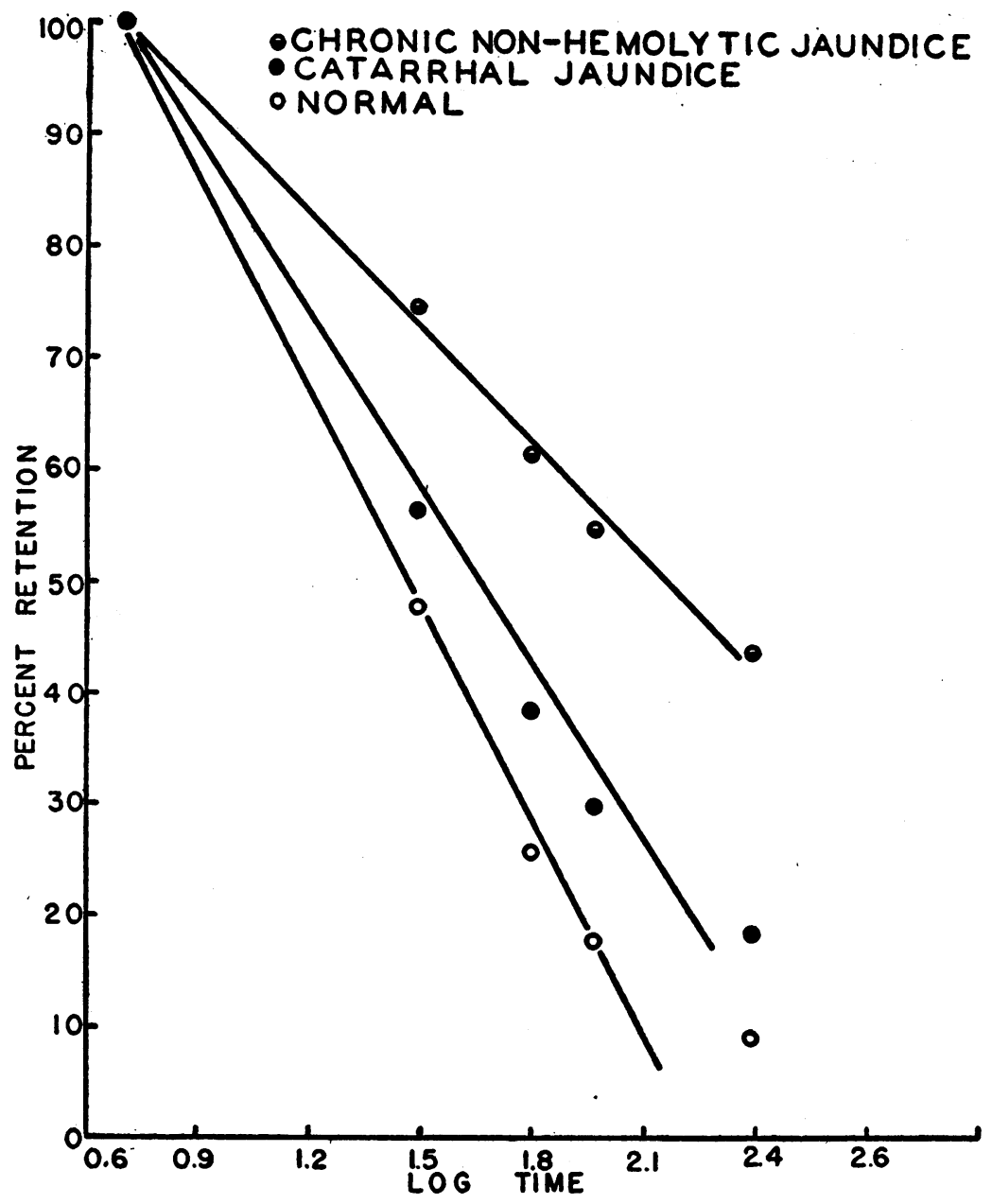

Fig. 2. Composite Curves of Mean Serum Bilirubin Values during the Excretion Test Plotted Against the Logarithm of Time

bohydrate and protein intake, he was discharged as improved.

Case 31. This 49-year-old laborer had catarrhal jaundice in August 1940. A gastro-intestinal series revealed a tender, incompletely filled duodenal cap; other studies were negative. Eight months later his basal bilirubin level was $1.22 \mathrm{mgm}$. per cent with a $\mathrm{D} / \mathrm{I}$ (direct: indirect) ratio of 0.38 and a 4-hour bilirubin retention of 47.8 per cent. His liver was firm and palpable $5 \mathrm{~cm}$. below the costal margin, but he was asymptomatic. He admitted moderate alcohol ingestion.

Case 33. This 20-year-old male has been studied in this clinic since the age of 14 . His most frequent complaints were malaise and shifting abdominal pains. In September 1938 he was hospitalized for a 2-day episode of unexplained diarrhea with high fever and in April 1940 for catarrhal jaundice. Three months later he returned to the Out-Patient Department with complaints of epigastric distress and flatulence. A gastro-intestinal series revealed a slightly irritable cap. The diagnosis was psychoneurosis. One year after his episode of jaundice, he still complained of malaise, anorexia, flatulence, irritability, and persistent pain in the upper abdominal quadrants. The basal bilirubin level was $0.860 \mathrm{mgm}$. per cent with a $D / I$ ratio of 0.31 and a 4-hour retention of 21.1 per cent. A gallbladder series was normal.

Case 40. This 29-year-old hospital orderly had catarrhal jaundice in September 1939. He had residual belching, flatulence, abdominal distension, and a dull aching pain in the right upper quadrant. He could obtain no medical relief and resorted to herb remedies. He felt irritable and tired, and drank moderate amounts of alcohol. One and a half years after his jaundice, the basal bilirubin level was $0.520 \mathrm{mgm}$. per cent, and he still retained 18.2 per cent of the injected bilirubin at 4 hours. His liver was tender and palpable $2 \mathrm{~cm}$. below the costal margin.

Case 45. This 16-year-old boy had catarrhal jaundice in February 1938. He visited the Out-Patient Department a few months after his recovery with complaints 
TABLE IV

Individual bilirubin excretion test values in persons long recovered from catarrhal jaundice, March 1941

The basal bilirubin values ranged from 0.264 to $1.280 \mathrm{mgm}$. per cent with a mean value of $0.616 \mathrm{mgm}$. per cent and a standard deviation of $0.252 \mathrm{mgm}$. per cent.

\begin{tabular}{|c|c|c|c|c|c|c|c|c|c|}
\hline \multirow{2}{*}{ Case number } & \multirow{2}{*}{ Age } & \multirow{2}{*}{$\begin{array}{c}\text { Interval } \\
\text { since } \\
\text { catarrhal } \\
\text { jaundice }\end{array}$} & \multicolumn{6}{|c|}{ Serum bilirubin } & \multirow{2}{*}{$\begin{array}{l}\text { Per cent } \\
\text { retention } \\
\text { at } 240 \mathrm{~min} .\end{array}$} \\
\hline & & & 0 minutes & 5 minutes & 30 minutes & 60 minutes & 90 minutes & 240 minutes & \\
\hline $\begin{array}{c}30(2 / 2) \\
(2 / 7) \\
(3 / 1) \\
31 \\
32 \\
33 \\
34 \\
35 \\
36 \\
37 \\
38 \\
39 \\
40 \\
41 \\
42 \\
43 \\
44 \\
45 \\
46\end{array}$ & $\begin{array}{c}\text { years } \\
11 \\
\\
49 \\
10 \\
19 \\
12 \\
23 \\
13 \\
15 \\
20 \\
13 \\
29 \\
7 \\
8 \\
15 \\
11 \\
15 \\
22\end{array}$ & $\begin{array}{c}\text { months } \\
4 \\
5 \\
8 \\
10 \\
11 \\
13 \\
13 \\
13 \\
14 \\
16 \\
16 \\
18 \\
23 \\
25 \\
24 \\
26 \\
38 \\
42\end{array}$ & \begin{tabular}{|c|} 
mgm. per cent \\
0.628 \\
0.503 \\
1.280 \\
1.220 \\
0.682 \\
0.863 \\
0.332 \\
0.660 \\
0.660 \\
1.010 \\
0.682 \\
0.522 \\
0.520 \\
0.400 \\
0.231 \\
0.574 \\
0.264 \\
0.503 \\
0.556
\end{tabular} & \begin{tabular}{|c|} 
mgm. per cent \\
3.040 \\
3.360 \\
5.090 \\
4.170 \\
3.950 \\
3.980 \\
2.990 \\
3.550 \\
3.120 \\
3.740 \\
3.430 \\
3.400 \\
3.710 \\
\\
2.490 \\
3.580 \\
2.870 \\
3.660 \\
3.630
\end{tabular} & \begin{tabular}{|c|} 
mgm. per cent \\
2.490 \\
2.360 \\
3.920 \\
3.180 \\
2.890 \\
2.780 \\
1.590 \\
2.540 \\
2.030 \\
2.910 \\
2.120 \\
2.030 \\
2.240 \\
1.360 \\
1.320 \\
2.260 \\
1.710 \\
2.380 \\
2.260
\end{tabular} & \begin{tabular}{|c|} 
mgm. per cent \\
2.030 \\
1.860 \\
3.520 \\
2.870 \\
2.300 \\
2.100 \\
0.992 \\
1.930 \\
1.690 \\
2.570 \\
1.400 \\
1.420 \\
1.820 \\
0.920 \\
0.920 \\
1.510 \\
1.240 \\
1.670 \\
1.630
\end{tabular} & $\begin{array}{c}\text { mgm. per cent } \\
1.950 \\
1.580 \\
3.220 \\
2.490 \\
1.970 \\
1.990 \\
0.808 \\
1.660 \\
1.380 \\
2.400 \\
1.180 \\
1.190 \\
1.380 \\
0.770 \\
0.700 \\
1.190 \\
1.010 \\
1.460 \\
1.440\end{array}$ & \begin{tabular}{|c|} 
mgm. per cent \\
1.560 \\
1.200 \\
2.870 \\
2.630 \\
1.360 \\
1.520 \\
0.610 \\
1.140 \\
1.180 \\
1.650 \\
1.030 \\
0.881 \\
1.100 \\
0.522 \\
0.452 \\
0.937 \\
0.736 \\
1.010 \\
0.937
\end{tabular} & $\begin{array}{r}37.6 \\
24.5 \\
41.8 \\
47.8 \\
20.8 \\
21.1 \\
10.5 \\
16.6 \\
21.1 \\
23.4 \\
12.7 \\
12.8 \\
18.2 \\
9.7 \\
12.3 \\
18.2 \\
16.1 \\
12.4\end{array}$ \\
\hline
\end{tabular}

of fatigue, abdominal and chest pain, headaches, severe constipation, and inability to attain his former proficiency at school. Three years later the basal bilirubin level was $0.503 \mathrm{mgm}$. per cent, and he retained 16.1 per cent of the injected pigment at 4 hours. The above mentioned symptoms were persistent.

3. Persons with chronic non-hemolytic jaundice. This group consists of 7 medical students and 1 graduate chemistry student (Case 54). It arose as a result of casual observations of less than 100 medical students and a selection of those who appeared to have an icteric tint to their sclerae. The laboratory studies of these individuals revealed the basal bilirubin level to be consistently elevated over a period of many months with a van den Bergh reaction indirect in type. The bilirubin excretion was markedly retarded in every instance, and in several individuals other tests of liver function yielded positive results. The hematological, x-ray, blood chemical, and urinary studies were uniformly negative. In Table $\mathrm{V}$ are the assembled data for this group, and in Figures 1 and 2 the composite bilirubin excretion curves are shown. Figure 3 contains the results of vitamin A absorption tests. ${ }^{1}$

1 At present a further group is being investigated. Among the first and second year medical classes, comprising approximately 120 persons, routine icterus indices
Some interesting data were obtained from clinical histories and physical examinations of these 8 individuals and they are summarized here.

Case 47. This 26-year-old male had catarrhal jaundice in September 1938. His icterus index upon discharge was 18 units. In October 1939 he had unexplained abdominal cramps and diarrhea for several days and a palpable liver and spleen. In October 1940 his basal bilirubin level was $1.5 \mathrm{mgm}$. per cent, he was asymptomatic, and his liver and spleen were no longer palpable.

Case 48. This 25-year-old male, at the age of 8 , had the "yellow jaundice." At the age of 17 he was exposed to carbon tetrachloride for 6 weeks, while working in a cleaning plant. He had drunk raw milk, and his agglutinin titre for Brucella melitensis was $1: 80$ in 1938. In 1939, he had a tuberculous pleural effusion with recovery, following a year of sanitorium care. Subicteric sclerae were noted in January 1940. In October 1940 his basal bilirubin level was $1.36 \mathrm{mgm}$. per cent.

Case 49. This 29-year-old male recalled having had "dirty-looking" eyes for many years. At the age of 19 he worked in a gasoline filling station for one year. At 21 years he had acute appendictis, generalized peritonitis, pelvic abscess, and finally recovered without re-

revealed 10 with elevated values. Bilirubin excretion tests on 6 of these persons, performed by Dr. E. B. Millard, Jr., demonstrated basal bilirubin values of $1.45,1.59$, $1.62,1.63,1.67$, and $1.75 \mathrm{mgm}$. per cent with 4-hour retention percentages of $79.2,70.7,58.9,70.9,31.5$, and 47.9 respectively. 


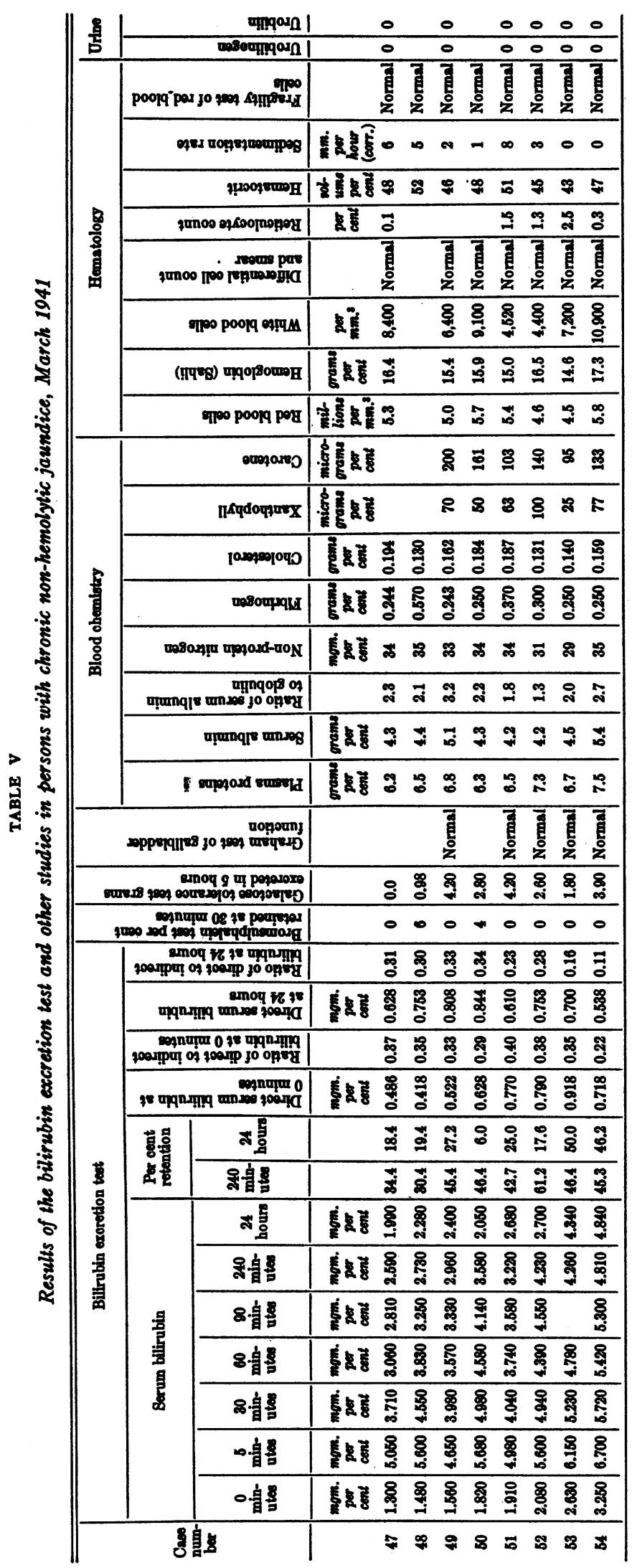




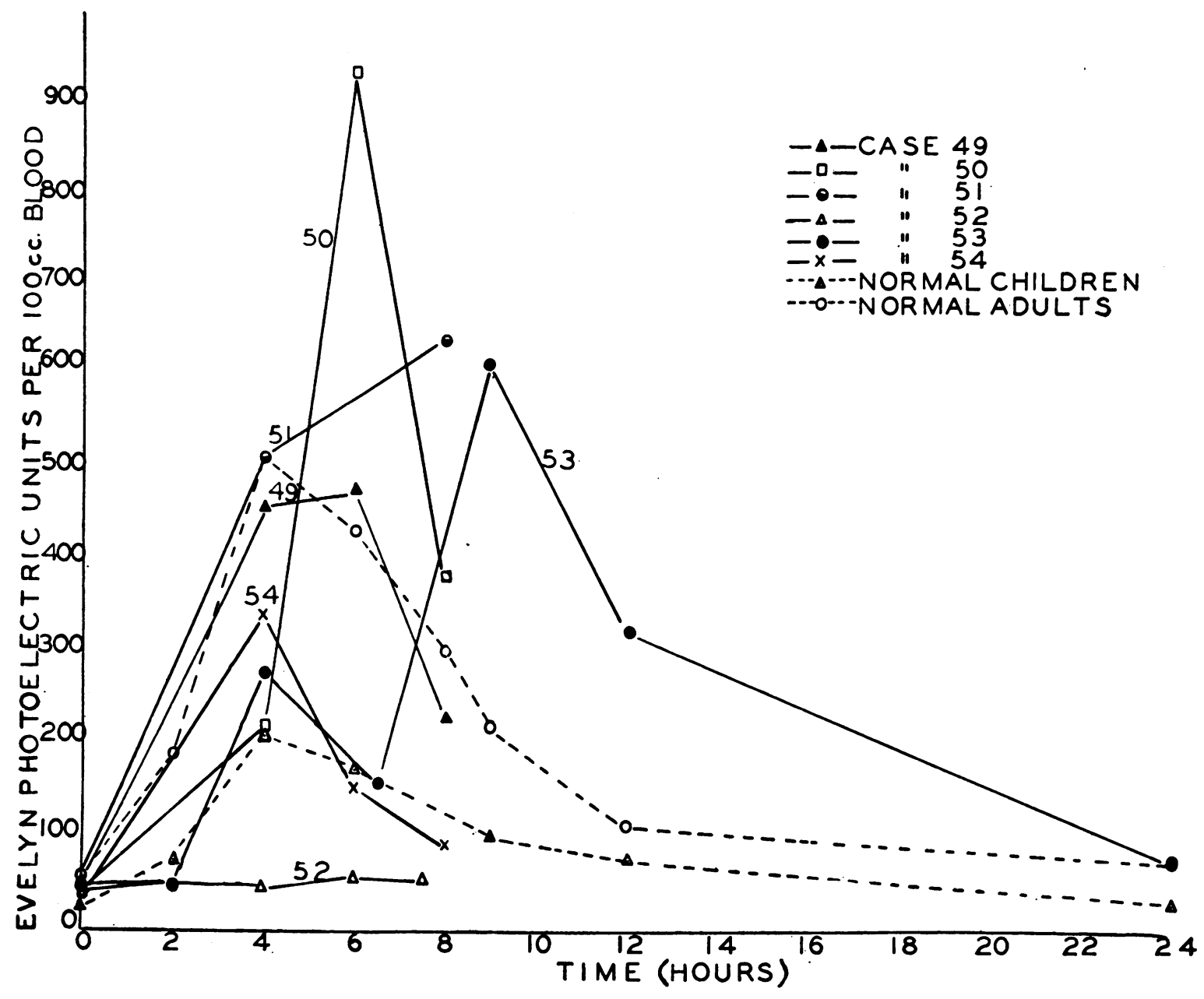

* i evelyn photoelectric unit = approximately 3.I

INTERNATIONAL UNITS

\section{Fig. 3. Vitamin A Absorption Test}

sidua. Subicteric sclerae were noted in 1939. In October 1940 his icterus index was 14 units.

Case 50. This 26-year-old male had jaundice neonatally and once or twice in childhood. Since 1938 he has had flatulence, constipation, occasional vomiting, and generalized discomfort after eating. These symptoms are aggravated by emotional upsets. He has chronic sinusitis. In October 1940 his icterus index was 14 units.

Case 51. This 25-year-old male had typhoid fever at 5 years. The icteric tint of his sclerae was noted in October 1940. In March 1941 his liver was tender and palpable $3 \mathrm{~cm}$. below the costal margin. He complained of occasional drawing right upper quadrant pains. A maternal grandmother died of obstructive jaundice.

Case 52. This 25-year-old male at 16 years aspirated a mercurial solution. This was followed by severe diarrhea for several days and then recovery. At 19 he had an appendectomy for chronic abdominal pain with some relief. At 20 a physician casually observed his sclerae to be yellow. The jaundice has been more notable during exacerbations of sinus disease. In April 1940 his icterus index was 22 units. All diagnostic procedures directed at the etiology of his jaundice during a hospital study were negative. Blood bilirubin levels of his family showed normal values for all but his mother, who had a level of $1.26 \mathrm{mgm}$. per cent with a D/I ratio of 0.36 . A maternal grandmother died of hepatic cirrhosis at 72 years after a lifetime of jaundice. ${ }^{2}$

Case 53. A 23-year-old male, whose jaundice was noted in November 1939, had at that time an icterus index of 14 units. He complained of flatulence, a partial

2 A bilirubin excretion test in November 1941 revealed a basal value of $2.25 \mathrm{mgm}$. per cent with a 4-hour retention of 64.3 per cent as compared with 61.2 per cent in March 1941. 
TABLE VI

Individual bilirubin excretion test values in persons with miscellaneous conditions

\begin{tabular}{|c|c|c|c|c|c|c|c|c|c|}
\hline \multirow{2}{*}{$\begin{array}{c}\text { Case } \\
\text { number }\end{array}$} & \multirow[b]{2}{*}{ Age } & \multirow{2}{*}{ Diagnosis } & \multicolumn{6}{|c|}{ Serum bilirubin } & \multirow{2}{*}{$\begin{array}{l}\text { Per cent } \\
\text { retention } \\
\text { at } 240 \\
\text { minutes }\end{array}$} \\
\hline & & & $\underset{\text { minutes }}{\text { o }}$ & $\left|\begin{array}{c}5 \\
\text { minutes }\end{array}\right|$ & $\stackrel{30}{\text { minutes }}$ & $\begin{array}{c}60 \\
\text { minutes }\end{array} \mid$ & $\begin{array}{c}90 \\
\text { minutes }\end{array}$ & $\begin{array}{c}240 \\
\text { minutes }\end{array}$ & \\
\hline $\begin{array}{l}61 \\
62 \\
64 \\
65 \\
66 \\
67 \\
68 \\
69 \\
70 \\
71 \\
72\end{array}$ & $\begin{array}{l}\text { years } \\
60 \\
18 \\
15 \\
59 \\
44 \\
65 \\
55 \\
57 \\
67 \\
10 \\
36\end{array}$ & $\begin{array}{l}\text { Carcinoma of pancreas } \\
\text { Hodgkin's disease } \\
\text { Lymphosarcoma } \\
\text { Lymphosarcoma } \\
\text { Chronic lymphatic leukemia } \\
\text { Chronic myelogenous leukemia } \\
\text { Carcinoma of liver } \\
\text { Portal cirrhosis } \\
\text { Portal cirrhosis } \\
\text { Paroxysmal hemoglobinuria } \\
\text { Hepatitis, convalescent }\end{array}$ & $\begin{array}{c}\text { mgm. per } \\
\text { cent } \\
4.550 \\
0.538 \\
0.366 \\
0.500 \\
0.503 \\
0.468 \\
0.592 \\
4.840 \\
0.736 \\
0.418 \\
0.592\end{array}$ & \begin{tabular}{|c|} 
mem. per \\
cent \\
6.920 \\
2.170 \\
2.490 \\
3.300 \\
2.700 \\
2.610 \\
2.990 \\
7.180 \\
3.920 \\
2.780 \\
3.090 \\
\end{tabular} & $\begin{array}{c}\text { mgm. per } \\
\text { cent } \\
5.920 \\
1.390 \\
1.230 \\
1.990 \\
1.820 \\
1.500 \\
1.860 \\
6.790 \\
2.440 \\
1.910 \\
1.650\end{array}$ & 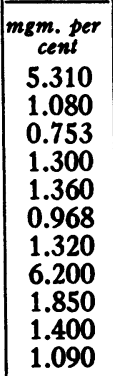 & 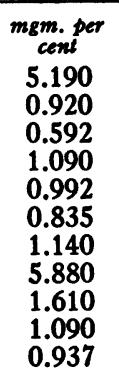 & \begin{tabular}{|c|} 
mgm. per \\
cent \\
4.980 \\
0.556 \\
0.880 \\
0.863 \\
\\
\\
5.340 \\
1.260 \\
0.881 \\
0.825
\end{tabular} & $\begin{array}{r}18.2 \\
8.2 \\
13.5 \\
16.3 \\
\\
\\
21.4 \\
16.4 \\
19.5 \\
9.6\end{array}$ \\
\hline
\end{tabular}

intolerance to fatty and fried foods, occasional shifting abdominal pains, and several episodes of unexplained diarrhea. Icterus levels were followed closely during the next year and varied between 10 and 20 units. Repeated $\mathbf{x}$-rays of the gallbladder and intestinal tract, and hematological and blood chemical studies were negative. His mother died of an operative complication of cholecystectomy for chronic cholecystitis and cholelithiasis. A sister has symptoms of gallbladder disease. A maternal aunt had a cholecystectomy many years ago and is jaundiced at present.

Case 54. Jaundice was discovered in this 24-year-old male during the routine blood chemical studies of individuals doing research with arsenical gases. Traces (1 gamma or less) of arsenic were found in the urine, hair, blood serum, and cells. Cadmium appeared as a trace in the urine, in a concentration of 3 gamma in the hair, and 10 gamma per cc. in the blood serum. He remembered volatilizing cadmium and sulphur in a crucible 1 year ago. There was no known exposure to free arsenical fumes.

4. Persons with miscellaneous conditions. The bilirubin excretion test was performed on a varied group of persons suspected of liver dysfunction. Positive results were obtained in 1 person with chronic leukemia, 2 persons with portal cirrhosis, and in 1 person with paroxysmal hemoglobinuria. Bilirubin excretion within normal limits occurred in 2 persons with lymphosarcoma and in 1 person recovering from jaundice coincident with pneumonia.

\section{DISCUSSION}

Observations of 29 presumably normal individuals indicate that the basal serum bilirubin level is generally below $0.8 \mathrm{mgm}$. per cent. Bilirubin injected in a dose of $1.5 \mathrm{mgm}$. per kilogram of body weight is excreted by these subjects in a relatively uniform way, the retention at 4 hours after injection never exceeding 15 per cent. A comparison of these results with those in the literature is difficult because of the diverse techniques employed.

A group of individuals, otherwise random, who were long recovered from a well-studied attack of catarrhal jaundice, differed significantly from these normal subjects. Of 16 individuals tested, 10 gave evidence of abnormal excretion of bilirubin and 4 of these 10 described symptoms of liver dysfunction, which prior to the test had been unexplained. Their complaints were vague abdominal pains, flatulence, anorexia, and general malaise. Hepatomegaly and jaundice occurred in several individuals. These laboratory and clinical findings are in close agreement with those described by Kalk (7) and Soffer (8) and serve to emphasize, along with the more recent concept of the pathogenesis of catarrhal jaundice, that this disease is not so completely benign as it is commonly regarded. Rather it is seen that longlasting impairment of liver function, often associated with a suggestive symptom complex, is a frequent residuum of an uncomplicated episode of catarrhal jaundice.

Eight cases of chronic non-hemolytic jaundice were discovered in a small body of medical students. Comparable experiences have been described by others. Polack (9) found 8 cases of jaundice in young persons which he ascribed to chronic hepatitis resulting from antecedent acute 
episodes. Meulengracht (10) saw 24 persons between the ages of 15 and 30 years who had mild chronic jaundice. He regarded the abnormality as a benign hepatic disorder rather than hemolytic jaundice, chronic hepatitis, or "physiological hyperbilirubinemia." A high incidence of medical students and physicians was noted in these groups, and it was attributed to the greater acuity of these persons in detecting slight degrees of jaundice.

A careful study of the individuals in the present series revealed a uniformly marked inability to excrete intravenously injected bilirubin. Galactose was excreted in excessive amounts in several members of the group, and one subject was unable to absorb ingested vitamin A. Bromsulphalein, $\mathrm{x}$-ray, hematological, blood chemical, and urinary studies were negative. The etiology and the precise nature of these disorders are not clear. Probably they are examples of low-grade parenchymal dysfunction which have arisen from one or several causes, such as exposure to poisons or inflammatory disease.

Soffer (11) and others have stated that the bilirubin excretion test is contraindicated in the presence of hyperbilirubinemia, because of the manifest inability of the individual to excrete bilirubin. While these theoretical objections may possibly hold in purely obstructive types of jaundice, they do not apply with equal force to other types of jaundice. In the present study useful information has been derived from the application of the test to persons with low-grade chronic non-hemolytic jaundice. Methods of calculation (Weech et al., 12) designed to eliminate the effect of elevated basal bilirubin levels, yield results, in this group of individuals, which do not differ from those reported here with the use of the conventional retention formula, originally proposed by Von Bergmann and Eilbott $(1,2)$. Also there are several reports $(13,2,7,14)$ of normal excretion in the presence of jaundice.

Von Bergmann and Eilbott found the rate of bilirubin excretion to be proportional to the concentration in the blood at any particular time. This relationship was not obtained from the present data. From the linear relation of the serum bilirubin values to the logarithm of time (Figure 2), it can be inferred that within limits the excretory rate varies inversely with time. Although simple, this relation gives little information about the kinetics of bilirubin removal.

Weech et al. (12) propose a formula for the measurement of bilirubin excretion based on the assumption that within certain defined limits the excretory rate is approximately proportional to the square of the plasma concentration. This formula was applied to the data of the present investigation, and the results were compared with those obtained with the conventional retention formula. The coefficient of correlation, " $r$ " (product moment), for the entire body of data was 0.68 and that for the group with chronic nonhemolytic jaundice, separately, was 0.86 .

Dragstedt and Mills (15) in studying the removal of intravenously injected bilirubin in dogs were puzzled by the low concentrations present in the serum 5 minutes after injection. They obtained only 40 per cent of the concentration calculated to be there if the material were distributed solely in the plasma, whereas in the present studies of human subjects these 5-minute values were usually close to 100 per cent. These workers (16) also concluded as a result of reticulo-endothelial cell blockade experiments in dogs, that bromsulphalein retention occurred whenever jaundice was present. However, the group of individuals with chronic non-hemolytic jaundice in this study showed no pathological retention of bromsulphalein.

\section{CONCLUSIONS}

1. Persons long recovered from catarrhal jaundice show an abnormal retention of bilirubin and possess symptoms of liver dysfunction in a considerable percentage of the cases.

2. Chronic non-hemolytic jaundice occurs in otherwise healthy young persons much more frequently than has been commonly recognized.

3. Presumably normal persons have basal bilirubin values which fall within a narrow range and excrete intravenously injected bilirubin in a relatively uniform way.

4. The bilirubin excretion test is a reliable and sensitive test of liver function.

I wish to express my gratitude to Professor William S. McCann whose encouragement made this work possible. I am also indebted to Mr. A. V. Wolf for his helpful advice throughout the course of this work. 


\section{BIBLIOGRAPHY}

1. Von Bergmann, G., Zur Funktionellen Pathologie der Leber insbesondere der Alkohol-Ätiologie der Cirrhose. Klin. Wchnschr., 1927, 6, 776.

2. Eilbott, W., Funktionsprüfung der Leber Mittels Bilirubinbelastung. Ztschr. f. klin. Med., 1927, 106, 529.

3. Malloy, H. T., and Evelyn, K. A., The determination of bilirubin with the photoelectric colorimeter. J. Biol. Chem., 1937, 119, 481.

4. Waugh, T. R., and Asherman, E. G., The use of an index of hemolysis in expressing the fragility of erythrocytes. J. Lab. and Clin. Med., 1938, 23, 746.

5. McCoord, A. B., and Luce-Clausen, E. M., The storage of vitamin $A$ in the liver of the rat. J. Nutrition, 1934, 7, 557.

6. Clausen, S. W., and McCoord, A. B., The determination of carotene and xanthophyll by a single distribution between liquid phases. J. Biol. Chem., 1936, 113, 89.

7. Kalk, H., Klinische Untersuchungen über die Frage des latenten Leberschadens. I. Untersuchungen mit der Bilirubinbelastungsprobe beim Ikterus Catarrhalis. Deutsche med. Wchnschr., 1932, 58, 1078; II. Klinische Untersuchungen bei den sogenannten Hepatopathien nach überstandenem Ikterus Catarrhalis. Ibid., 1932, 58, 1119.
8. Soffer, L. J., and Paulson, M., Residual hepatic damage in catarrhal jaundice as determined by the bilirubin excretion test. Arch. Int. Med., 1934, 53, 809.

9. Polack, E., Chronic hepatitis in young persons with or without intermittent jaundice. Acta med. Scandinav., 1938, 93, 614.

10. Meulengracht, E., Icterus Intermittens Juvenilis (Chronischer Intermittierender Juveniler Subikterus). Klin. Wchnschr., 1939, 18, 118.

11. Soffer, L. J., and Paulson, M., Comparative advantages and further modifications of the bilirubin excretion test for hepatic function. Am. J. M. Sc., 1936, 192, 535.

12. Weech, A. A., Vann, D., and Grillo, R. A., The clearance of bilirubin from the plasma. A measure of the excreting power of the liver. J. Clin. Invest., 1941, 20, 323.

13. Damashek, W., and Singer, K., Familial nonhemolytic jaundice. Arch. Int. Med., 1941, 67, 259.

14. Lin, H., and Eastman, N. J., The behavior of intravenously injected bilirubin in newborn infants. Am. J. Obst. and Gynec., 1937, 33, 317.

15. Dragstedt, C. A., and Mills, M. A., The removal of intravenously injected bilirubin from the blood stream in the dog. Am. J. Physiol., 1937, 119, 713.

16. Dragstedt, C. A., and Mills, M. A., Bilirubinemia and bromsulphalein retention. Proc. Soc. Exper. Biol. and Med., 1936, 34, 467. 